\title{
Globalization of Corporate Social Responsibility Focussing On Indian Markets.
}

\author{
Soheli. Ghose, \\ Assistant Professor, Department of Commerce \\ J.D.Birla Institute (Jadavpur University), India.
}

\begin{abstract}
In recent years, scholars and managers have devoted considerable attention to the strategic implications of corporate social responsibility (CSR). CSR can be defined as situations where the firm goes beyond compliance and acts to further some social good, beyond the interests of the firm and that which is required by law. CSR activities have been posited to include incorporating social characteristics or features into products and manufacturing processes (aerosol products with no fluorocarbons, environmentally-friendly technologies), adopting progressive human resource management practices (promoting employee empowerment), achieving higher levels of environmental performance through recycling and pollution abatement (reducing emissions), and advancing the goals of community organizations (working closely with groups such as United Way). In this context I have studied the theoretical aspect of CSR including the Global Reporting Initiative and CSR Legislation norms and globalization of CSR in the including India. I have also studied few specific cases of CSR activity and CSR violation in India.
\end{abstract}

Key Words: Corporate Social Responsibility Reporting, Global Reporting Initiative, Legislation in Corporate Social Responsibility, OECD norms.

\section{Introduction}

The world cannot get out of its current state of crisis with the same thinking that got it there in the first place. ALBERT EINSTEIN. World Business Council for Sustainable Development defines Corporate Social Responsibility (CSR) as "The continuing commitment by business to behave ethically and contribute to economic development while improving the quality of life of the workforce and their families as well as of the local community and society at large." CSR can be thus be simply defined as the additional commitment by businesses to improve the social and economic status of various stakeholders involved while complying with all legal and economic requirements. McWilliams and Siegel (2001) [1], defined CSR as situations where the firm goes beyond compliance and acts to further some social good, beyond the interests of the firm and that which is required by law.As Warhurst (2001) [2] points out, the three major elements of CSR are product use which focuses on contribution of industrial products which help in well being and quality of life of the society, business practice which focuses on good corporate governance and gives high impetus for the environmental well being and equity which tries for distribution of profits equitably across different societies especially the host community. CSR has a significant role in controlling the perils of uncontrolled development, satisfying the needs of the present generation and at the same time ensuring that the resources of future generations is not jeopardized. Companies are more willing to report on their contributions to the maintenance of a sound environment, a healthier society or more ethical business practices through both internal and external action within the countries in which they operate. The area often lacking is CSR reporting in the area of labour rights and relations. One of the prime concerns of CSR should be the quality of industrial relations within a company. There will be increased costs to implement CSR, but the benefits are likely to far outweigh the costs.

\section{Rationale behind Corporate Social Responsibility}

The current trend of globalization has made the firms realize that in order to compete effectively in a competitive environment they need clearly defined business practises with a sound focus on the public interest in the markets (Gray, 2001) [3]. Firstly, the increase in competition among the multinational companies to gain first mover advantage in various developing countries by establishing goodwill relationships with both the state and the civil society is ample testimony to this transformation. Secondly, in most of the emerging markets, the state has a duty of protecting the interests of the general public and thus gives preference to companies which take care of the interests of all the stakeholders. Thirdly, emerging markets have been identified as a source of immense talent with the rising levels of education. In order to draw from this vast talent pool coming up in developing countries, companies need to gain a foothold in these markets by establishing sound business practices addressing social and cultural concerns of the people. It has been observed that consumers consider switching to another company's products and services, speak out against the company to family/friends, refuse to invest in that company's stock, refuse to work at the company and boycott 
the company's products and services in case of negative corporate citizenship behaviours (Edenkamp, 2002) [4]. Fourthly, firms all over the world are beginning to grasp the importance of intangible assets, be it brand name or employee morale. Only firms that have gained the goodwill of the general public and are ideal corporate citizens will be to develop these intangible assets into strategic advantages. Fifthly, CSR is an important factor for employee motivation and in attracting and retaining top quality employees as well. Innovation, creativity, intellectual capital and learning are helped by a positive CSR strategy. Sixthly, better risk management can be achieved by in-depth analysis of relations with external stakeholders.

\section{Theoretical Perspectives on CSR}

Numerous theories have been brought to bear on the subject of CSR.

Theodore Levitt (1970) [5], in his HBR article "The Dangers of Social Responsibility," cautions that "government's job is not business, and business's job is not government".

Milton Friedman (1970) [6], added that the mere existence of CSR was a signal of an agency problem within the firm. An agency theory perspective implies that CSR is a misuse of corporate resources that would be better spent on valued-added internal projects or returned to shareholders. It also suggests that CSR is an executive perk, in the sense that managers use CSR to advance their careers or other personal agendas.

Another perspective, stewardship theory (Donaldson, 1990) [7] is based on the idea that there is a moral imperative for managers to "do the right thing," without regard to how such decisions affect firm's financial performance.

Institutional theory and classical economic theory have also been applied to CSR in a paper by Jones (1995) [8]. He concludes that companies involved in repeated transactions with stakeholders on the basis of trust and cooperation are motivated to be honest, trustworthy, and ethical because the returns to such behaviour are high.

\subsection{Principles of social responsibility}

Level 1: This level defines the institutional relationship between business and society at large, and specifies what is expected of any business. It has three major elements:

\# Legitimacy concerns business as a social institution, and frames the analytical view of the inter-relationship between business and society;

\# Public responsibility concerns the individual firm and its processes and outcomes within the framework of its own principles in terms of what it actually does;

\# Managerial discretion, whereby managers and other organizational members obliged to exercise their discretion towards socially responsible outcomes.

Level 2 (Process): Three elements are identified as being basic to this level of the CSR model:

\#Business environment scanning indicates the informational gathering arm of the business and the transmission of the information gathered throughout the organization.

\# Stakeholder management refers to mapping the relationships of stakeholders to the firm (and among each other) whilst finding, listening and meeting their expectations that legitimate concerns should be balanced and met as a prerequisite for any measurement process.

\# Management Issues refers to applying the principles to issues concerning stakeholders.

Level 3 (Outcomes): This focuses on measurement. All of the stakeholders relevant to an issue must be included in any assessment of performance. There are three main categories:

\# Internal stakeholder effects are those that affect stakeholders within the firm. It shows how a corporate code of ethics affects the day-today decision making of the firm with reference to social responsibility. It may also be concerned with human resource policies, such as the positive or negative effects of corporate hiring and employee benefits practices.

\# External stakeholder effects concern the impact of corporate actions on persons or groups outside the firm. They may involve the negative effects of a product recall, the positive effects of community-related corporate philanthropy or, assuming that the natural environment is a stakeholder, the effects of toxic waste disposal.

\# External institutional effects refer to the effects upon the larger institution of business, rather than on any particular stakeholder group. For example, several environmental disasters have made the public aware of the effect of business decisions on the general public, bringing about pressure for environmental regulation, affecting the entire institution of business.

\subsection{CSR Reporting:} REASONS: 
\#Providing information about challenges and achievements to shareholders, employees, the public and other stakeholders.

\#An internal commitment to environmental and social responsibility and becoming a world leader in sustainability.

\#As a marketing tool, associating the company with sound environmental management and sustainable activities.

\#Tracking progress on integration of sustainability principles into company planning and programs.

\#A successful pilot project persuades decision-makers to take the initiative company-wide.

Moon (2002) [9] distinguishes three types of CSR reporting 'community involvement', 'socially responsible production processes' and 'socially responsible employee relations'. As compared with the developed countries like US, CSR in developing countries is seen as part of corporate philanthropy where corporations augment the social development to support the initiatives of the government. CSR is considered inbuilt in the business existence of the traditional firms in the emerging markets like India (Mohan, 2001) [10]. As companies start to embrace CSR practices to a greater extent, it changes production processes so that all environmental and societal norms are also satisfied even though they may not contribute to the profit maximising objective of the firm. This means that human rights agreements are also upheld considering the rights of the local communities. CSR also leads to evolution of employee relations in the company in such a way that employees become major stakeholders with definite decision making powers especially in the area of formulation of CSR policy. The comparative study of these parameters by Chambers, Chapple, Moon and Sullivan (2003) [11] show that currently Asian nations are still faring strongly only in the first parameter of community involvement.

\section{Globalization and Corporate Social Responsibility}

With globalization, it seems the negative consequences of businesses have intensified, as has the public call for corporate responsibility. Paradoxically, today, business firms are not just considered the "bad guys", causing environmental disasters, financial scandals, and social ills. They are at the same time considered the solution of global regulation and public goods problems as in many instances state agencies are completely unwilling to administer citizenship rights or contribute to the public good. The global framework of rules is fragile and incomplete. Therefore, business firms have an additional political responsibility to contribute to the development and proper working of global governance.

Considering the legal and moral rules of nationally bound communities as the point of reference for corporate legitimacy becomes a challenge against the background of a globally expanded corporate playing field (Palazzo and Scherer 2006) [12]. Obviously, there are no globally enforceable legal standards or broadly accepted moral rules that might circumscribe the legitimate activities of multinational corporations.

\subsection{CSR and Legislation}

With globalization an increasing number of companies are already focusing voluntarily on CSR issues, but it is clear, in the light of the poor corporate governance that resulted in both the Enron and World Com debacles, that some further form of legislation is necessary. A balance has to be made between no regulation and full regulation.

\section{Advantages of legislation:}

\# It would help to avoid the excessive exploitation of labour, bribery and corruption.

\# Companies would know what is expected of them, thereby promoting a level playing field.

\# Many aspects of CSR behaviour are good for business (such as reputation, human resources, branding and making it easier to locate in new communities) and legislation could help to improve profitability, growth and sustainability.

\# Some areas, such as downsizing, could help to redress the balance between companies and their employees. \# Rogue companies would find it more difficult to compete through lower standards. The wider community would benefit as companies reach out to the key issue of underdevelopment around the world.

\section{Disadvantages of legislation:}

\# Additional bureaucracy, with rising costs for observance.

\# Operation costs could rise above those required for continued profitability and sustainability.

\# Critics say that the CSR of companies is simply to make a profit, and legislation would increase the vocalization of these concerns.

\# Reporting criteria vary by company, sector and country, and they are in constant evolution.

\subsubsection{Benchmarks used by companies-CODES}


Some companies are often cited as the role models - the Body Shop was one of the first. Subsequently, a number of well-known companies, such as Shell and British Telecom, led the way, while smaller companies, including Van City (a Canadian Bank) and the Co-operative Bank (United Kingdom), have become role models. On the other hand, there are literally hundreds of codes of conduct and principles around the world. Few have a theoretical basis for their codes, while many simply cover just one or at most two stakeholders. There is a serious need for rationalization for companies to be clear about what is expected of them.

The codes, conventions, principles and standards aim towards improving the behaviour of corporations, and more appear to be emerging every day. An OECD [13] report identifies 233 codes of practice and an ILO report several hundred. Codes vary according to the areas that they cover. The OECD report categorizes five main areas of conduct: (a) fair business practices; (b) observance of the rule of law; (c) fair employment and labour rights; (d) environmental stewardship; and (e) corporate citizenship. Codes also vary according to the sponsoring organization or partnership. The OECD Guidelines for Multinational Enterprises (the Guidelines), first adopted in 1976, are the longest standing initiative for the promotion of high corporate standards. The Guidelines contain voluntary principles and standards for responsible business conduct in areas such as human rights, supply chain management, disclosure of information, anticorruption, taxation, labour relations, environment, competition, and consumer welfare.

\section{Advantages of endorsement of codes:}

\# raises stakeholder confidence;

\# demonstrates corporate prevention rather than response to crises; and acknowledges corporate peer pressure for higher standards of accountability and transparency.

\section{Disadvantages of endorsement of codes:}

\# Code proliferation is a counter-productive distraction that should be ignored;

\# there is no unique, unchangeable and widely accepted code;

\# Codes do not account for the running of a company and its major concerns to survive and avoid takeover or bankruptcy;

\# Codes may lead to third party certification that is costly and without added value.

\# One of the biggest problems faced by devisers of codes of conduct or principles of behaviour is what conceptual basis to use.

\subsubsection{Recent prominent codes}

Global Reporting Initiative (GRI) Reporting Guidelines, AA1000 Assurance Standard (AA1000AS), SA8000, United Nations Global Compact (UNGC), Framework for Public Environmental Reporting (Australia), General Guidelines on Environmental Reporting (UK), Environmental Reporting Guidelines (Japan), Der Leitfaden "Der Nachhaltigkeitsbericht" (Germany). Around 25 different guidelines are published by governments and institutions worldwide. The GRI is intended to help companies produce social reports. SA800035 and the United Nations Global Compact admit to setting standards for company behaviour, the former for the labour stakeholder group and the latter for three stakeholder groups: labour, environment and the community (human rights).

\subsubsection{UN initiatives}

UN Global Compact:_Introduced in 1999, the UN Global Compact (Compact) is a voluntary initiative based on 10 core principles relating to human rights, labour standards, the environment and anticorruption. The Compact's 10 principles enjoy consensus across many jurisdictions and are derived from: The Universal Declaration on Human Rights; The International Labour Organization's Declaration on Fundamental Principles and Rights at Work; The Rio Declaration on Environment and Development; and The United Nations Convention Against Corruption. The Compact is considered to be the world's largest corporate responsibility initiative, with 3000 corporate participants and other stakeholders involved.

UN Norms:-The UN Norms on the Responsibilities of Transnational Corporations and other Business Enterprises with regard to Human Rights attempts to establish a comprehensive legal framework for the human rights responsibilities of companies. The UN Norms state that MNEs have an obligation to 'promote, secure the fulfillment of, respect and protect human rights recognized in international and national law'. The UN Norms are not legally binding.

Principles for Responsible Investment:-The Principles for Responsible Investment (PRI), issued in April 2006, is a voluntary initiative which strives to identify and act on the common ground between the goals of institutional investors and the sustainable development objectives of the UN. The audience targeted is the 
global community; however the focus is on the eleven largest capital markets, with a goal of protecting the long term interests of fund beneficiaries. The PRI were borne from the perceived disconnect between corporate responsibility, and the behaviour of financial markets. The PRI, developed by leading institutional investors and overseen by the UN Environment Programme Finance Initiative and the UN Global Compact, includes environmental, social and Tripartite Declaration of Principles concerning Multinational Enterprises and Social Policy.

Global Reporting Initiative:_The Global Reporting Initiative (GRI), convened in 1997, was established to improve sustainability reporting practices, while achieving comparability, credibility, timeliness, and verifiability of reported information. The Guidelines, first released in June 2000, revised in 2002 with a revision due during 2006, seek to develop globally accepted sustainability reporting guidelines. These guidelines are also voluntary and are used by organisations in reporting on the economic, environmental, and social dimensions of their activities. Approximately 1000 organisations worldwide incorporate the GRI's Guidelines into their reporting. Some Indian companies which report as per GRI guidelines are ABN Amro Bank NV, ACC Ltd, Dr. Reddy's Laboratories Ltd, ITC Ltd, Reliance Industries Ltd, Shree Cement Ltd, Tata Consultancy Services, Tata Steel Ltd, Tata Tea Ltd and others.

Globalization and the significant growth and influence of the private sector have highlighted issues such as CSR and the regulation of MNEs.

Despite these initiatives, there still remains a gap in legal accountability of CSR practices, particularly in relation to MNE operations in jurisdictions outside their home state. To maximize the benefits of international investment corporations must operate within a clear framework of governance, underpinned at national and international level by law and regulation enforceable either by the company's home state or by a court of international standing, e.g., the International Court of Justice. In addition national laws should be widened to enable corporations to be held accountable for inappropriate conduct, in jurisdictions outside their home state.

\section{V. $\quad$ Csr - The Indian Scenario}

Corporate Social Responsibility in India is finally a 'reality'. Indian businesses realized they have to look not only at the economic dimension of their company, but also at its ecological and social impact - the three pillars of CSR. However, to become a planned strategy integral to business success, Indian companies have lot of catching up to do. CSR is also linked to the broader issue of "Corporate Governance. Needless to emphasize that Indian companies have to take a closer look at CSR and link it to corporate governance, if they really want to make a mark in all the three pillars of CSR.

According to a recent pilot survey by CII in Tamil Nadu, (Express Buzz) only 40 per cent of the companies practice CSR initiatives. The pilot survey, highlighted that a majority of the companies did not take CSR seriously and those who did, did it only with a philanthropic frame of mind. The pilot survey also revealed that more than 50 per cent of the companies made their employee welfare activities as part of their CSR initiative, not really contributing to an outside community or its development. Sustainable CSR programmes mean a cohesive mix of economic, legal, ethical and philanthropic tenets. In today's changed business scenario, there is an increased focus on giving back to society and creating a model which works long term and is sustainable and it is imperative that the best practices for inclusive growth are shared with the stakeholders.

\subsection{Violation of CSR principles in India - A few cases}

Recent rash of scandals involving major corporate giants throughout the world have brought to the attention of public and academia the need to analyze these issues.

Coca Cola: The plant at Plachimada was alleged to have exploited the ground water resources leading to drying up of wells and other natural water resources in the area. The entire region, which was a thriving agricultural land, had to rely on water supplied by tankers. Coca Cola was drawing 1.5 million litres/day from the common groundwater resource. However due to inherent water scarcity the company is able to extract only 800,000 litres from the bore wells. The company drew water from the nearby villages to compensate for the lack of availability causing parched lands of more than 2000 people residing within 1.2 miles of the factory (Jayaraman, 2002) [14]. The Coca Cola Company had to deal with protests from the local community and supporting environmental conservation groups. Adding to the water exploitation, Coca Cola was accused of supplying poisonous waste as fertilizer to the local farmers. Tests done by an independent agency on the behalf of BBC showed that the sludge contained high levels of Lead and Cadmium (Srivastava, 2004) [15]. The sludge, which was disposed off in open ground, ran along with rainwater to the natural water resources. The contamination caused by the sludge has allegedly caused allergic symptoms and perpetual headache to the local population. Tests also show that the water available in the wells is contaminated and unsuitable for consumption (Iype, 2003) [16]. The company had to face similar accusations from various parts of the country. 
In Varanasi, the local community protested against Coca Cola for exploiting water resources and spilling waste into the sacred Ganges. Added to these were the findings from the Centre for Science and Environment that twelve large soft-drink brands manufactured by Coca-Cola and its rival Pepsi, sold in and around Delhi, contained a cocktail of pesticide residues, including chemicals which can cause cancer, damage the nervous and reproductive systems and reduce bone mineral density.

The protests from the local community have led to worldwide reaction and have even led to open campaigns for boycott of products of Coca Cola. The government of Kerala also ordered the stopping of operations of the plant at Plachimada to safeguard the interests of the local community. There were campaigns for international boycott of Coca Cola's products (Atlanta IMC, 2003). In India the protests were also directed against MNCs in general, as there were demands for irresponsible MNCs to leave the country. Coca Cola responded to these by litigations in the court and applying pressures through its power centres in US. Public Relations agencies were hired to neutralize the situation. The company also issued releases which mentions about its socially responsible behaviour and good corporate citizenship.

The case clearly shows that emerging markets can respond and protest against irresponsible behaviours of MNCs and that emerging markets might have loose laws, which do not protect the interests of the local population, or laws that are not implemented properly.

Satyam: Satyam was recognized for its work with the Byrraju Foundation, founded by Ramalinga Raju, Chairman of Satyam Computers. Byrraju Foundation builds progressive, self-reliant rural communities in India through a holistic, transformational approach. So far, the Byrraju Foundation's work has impacted more than 3 million people in 199 villages in six districts of Andhra Pradesh. It will expand into other states shortly. Presently Chairman Ramalinga Raju has been accused for misleading stake holders and government for wrong accounting practices.

The Bhopal Gas Disaster: In the year 1984 chemical gas leaked from the Union Carbide plant in Bhopal. Referred as the worst industrial disaster in human history, on the horrific night of December 2nd and 3rd, more than 40 tons of the deadly gas methyl isocyanate escaped from the pesticide factory. Approximately half a million people were exposed to the gas and 20,000 have died to date as a result of their exposure. More than 120,000 people continue to suffer from severe health ailments related to the accident and contamination. In 2001, the US-based gigantic Dow Chemical purchased Union Carbide, thereby acquiring its assets and liabilities. However it has been steadfastly refusing to clean up the site, provide safe drinking water or compensate the victims, or even disclose the composition of the gas leak, Dow, like UCIL earlier, claims that it has no liability of the past. The Dow Chemical Company, with annual sales of $\$ 28$ billion, says in its web site: it is "committed to the principles of Sustainable Development and its approximately 50,000 employees seek to balance economic, environmental and social responsibilities."

The Unilever Case: In 2001 the Unilever Company dumped 300 metric tons of mercury at Kodaikanal located at South India. As a contrast to the above activity the Unilever website states, "We are committed to conducting our operations with integrity and with respect for the interests of our stakeholders. We are also committed to making continuous improvements in the management of our environmental impacts and to working towards our longer term goal of developing a sustainable business." In order to tackle above situations a new initiative was taken by Government of India that is CREP or "The Corporate Responsibility for Environmental Protection in 2003. A guideline for a set of non-mandatory norms for 17 polluting industrial sectors has been set but there is no real pressure for implementation or internalization. An ethical being which claims to respect the earth cannot have discontinuities in its practices. This can be no different for individuals as for companies. Contrast to the above news the Unilever website states "All Unilever companies must comply with local laws and adopt the same standards for occupational health and safety, consumer safety and environmental care."

Emerging markets like India have drawn the attention of large MNCs for the potential of market growth. However many MNCs also take the markets for granted and exploit the laxity in the norms of operations to their advantage. The negative publicity caused by the actions of MNCs has led to suspicion about their operations in the public in these markets. Getting multinationals to comply with local laws is not an easy task. Many countries do not direct sufficient resources to enforcement. Management practices that evade regulations persist. Furthermore, labor laws can indeed be difficult to interpret. One can hope that the companies' attitude towards CSR is more on transformation rather than giving information in web sites.

\subsection{Indian Companies Setting Standards}

Few Companies which are setting standards in CSR and are leading by example are ABN AMRO Bank NV (India),ACC Ltd, Accenture Services Pvt Ltd, Ashok Leyland, Bajaj Auto Ltd, Bharat Heavy Electricals Ltd, Bharti Airtel Ltd, Dr Reddy's Laboratories Ltd, Ford India Ltd, Grasim Industries Ltd ,HDFC Bank Ltd ,Hindustan Lever Ltd, Housing Development Finance Corporation, Icici Bank Ltd, Infosys 
Technologies Ltd, ITC Ltd, Jubilant Organosys Ltd, Kansai Nerolac Paints Ltd, Larsen \& Toubro Ltd, Mahindra \& Mahindra Ltd, Maruti Udyog Ltd, MSPL Ltd, National Thermal Power Corporation Ltd, Nerolac Paints Ltd, ONGC, Relaince Communications Ltd, Reliance Industries Ltd, Sesa Goa ltd, Sharp India Ltd, Sony India Pvt Ltd, SRF Ltd, SBI, SAIL, Tata Consultancy Services Ltd, Tata Motors Ltd, Tata Steel Ltd, Tata Tea Ltd, Tata Group, Tata Iron and Steel Co Ltd, Toyota Kirloskar Motor Pvt Ltd, Wipro Corporation, Yes Bank Ltd and others.

\section{Recent CSR Activities in India - Case Studies}

HSBC (India) team initiative is an example of how the "world's local bank" addresses global issues like climate change and eco-system conservation through local projects that actively engage its people. Some major initiatives towards CSR in the past few years are as follows:

May 2007: Hope for a Bright Future - The HSBC team went to Future Hope, an NGO in Kolkata working for street children, by giving them rehabilitation and education and a "Future", for a training session. The session was for the members of the Future Hope family - 20 young ladies and gentlemen, who are about to face the big world outside. The LDV team specially prepared a module to support the "Future First" initiative to ensure that the training offered was specific and "practically useful" for the participants. The sessions were spread over three days focusing on tips on job search, how to write good resumes, interviews and GDs.

June 2007: HSBC conferred with 'The Corporate Social Responsibility Award' by Rotary Club of Madras for the work implemented by HSBC for tsunami rehabilitation. HSBC's relationship with the Rotary Club of Madras goes back to the time when the tsunami first struck the Indian coastline in 2004. Since then HSBC and Rotary have collaborated on various community projects, like providing livelihood opportunities to fisher folk in the aftermath of tsunami through mechanized boats and fishing nets; or helping in the construction of a school; or helping create a healthy local economy through providing refrigeration plant and storage space for fish stock. A recent Rotary Golf Tournament organized by HSBC to raise funds for tsunami projects.

August 2008: A CSR initiative titled "We Care" was carried out aiming at providing solidarity to the underprivileged and the needy. The collections team of HSBC Bank across all the metro locations devoted their time in visiting Orphanage Homes, Old Age Homes, and Blind School for Children, Missionaries of Charity etc. The team spent a memorable time with the inmates by interacting with them, distributing basic items, eateries, stationeries, sweets, organizing games \& competitions, gifts, etc.

April 2009: HSBC supported Operation Kachappa, a conservation programme for the endangered Olive Ridley Turtles run by the Wildlife Protection Society of India (WPSI). Besides supporting WPSI through funds (e.g. the PFS team in Mumbai raised pledges for the Olive Ridleys at the Mumbai Marathon 2009), HSBC also supported the project through employee volunteering activities led by the Eastern India team. The team actively engages with this project every year through volunteering activities organized especially during the turtle nesting and hatching season. The team of HSBC Eastern India visited the area for the mass nesting. This is an ongoing project till now.

\section{UNIDO CDP \& CSR Project:}

The project aims to look into issues in a practical and action-oriented manner to ascertain if CSR compliance is more feasible and sustainable for SMEs that are located within clusters on account of the greater potential for coordinated private partnerships within such geographical concentrations. Its developmental objective is to further enable a greater number of small and medium manufacturing enterprises in developing countries improve their overall competitiveness in a socially responsible way, and, therefore, integrate more successfully and sustainably into national and international supply chains. The immediate objective of this project is to explore and start addressing the reasons behind the low level of participation of SMEs from developing countries in the CSR movement. Such low participation raises serious doubts on the capacity of many SMEs from developing countries to effectively integrate into regional/global value chains but also to ensure a sustainable and harmonious rate of growth.

To begin with, the Jalandhar Sports Goods Cluster (Punjab) was chosen for the project site in India, as UNIDO has already been involved in building competitiveness of this industry since 2002 to 2005. UNIDO aims to assess and facilitate the CSR related needs of the various stakeholders in the cluster, including capacity building of the entrepreneurs, the industry associations, the workers as well as the local community. Basically, it concerns 3 main areas: the in-factory compliance issues for SMEs, the philanthropic community level involvement of enterprises and the sharing of 'CSR-business case' best practices within the cluster.

\section{Conclusion}

CSR has a wide ranging effect across the globe especially in emerging markets. As discussed in this paper, in India CSR is still at a very nascent stage. Corporate leaders and their general counsels have to give compliance issues a higher priority as they recognize the risk of increased scrutiny on the legal angle of their global operations. Companies report legal compliance, making a stronger indicator of actual working 
conditions. The socially responsible investment community would do well to separate out legal requirements and form one assessment on these, and then evaluate a company on "beyond compliance" issues. Upper management must be persuaded to support not only CSR goals, but regulatory recommendations as well.

Legislation also needs to be made more universal (with certain culture specific modifications). This is very important in the face of globalization. There needs to be an integration of various CSR codes, standards for their proper application. Most importantly, a regular monitoring of a company's CSR activities is required both by the state and by the company itself. CSR is the need of the hour. Every company (especially MNCs) needs to emphasize on CSR activities to strengthen their market position, improve goodwill and thereby profitability and last but not the least to give back something positive to the society and environment

\section{FIGURES}

Figure 1. Best Indicators of CSR:

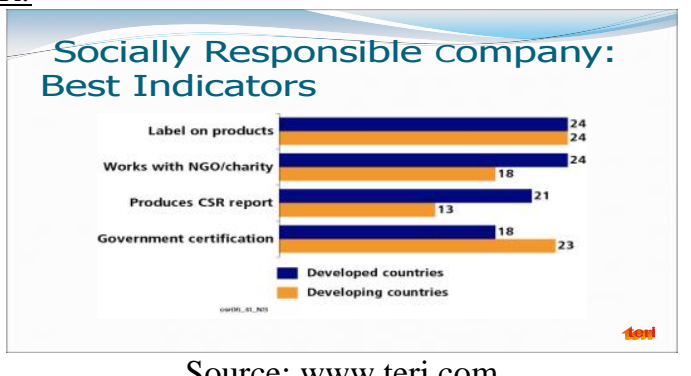

Source: www.teri.com

Figure 2. CSR Report Output:

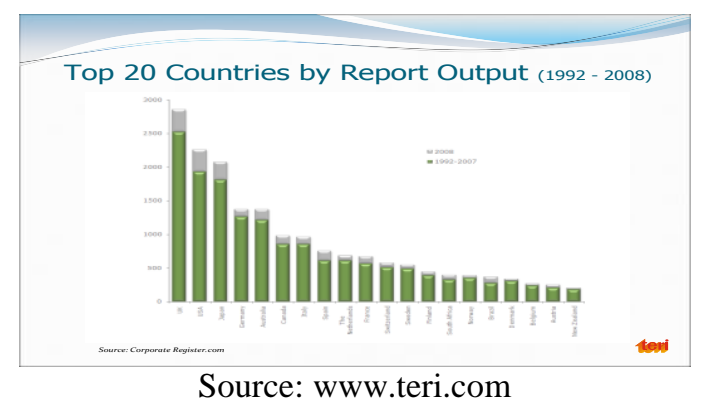

Reference:

[1]. McWilliams and Siegel, Corporate Social Responsibility: A Theory of the Firm Perspective, Academy of Management Review, 26, 2001, 117-127.

[2]. Warhurst, Corporate Citizenship and Corporate Social Investment: Drivers of Tri-Sector Partnerships, Journal of Corporate Citizenship, Spring, 2001, 57-73.

[3]. Gray, R. (2001). Social and Environmental Responsibility, Sustainability and Accountability, Can the Corporate Sector Deliver? Glasgow, Centre for Social and Environmental Accounting Research, UniversityofGlasgow.(www.agendascotland.org/documents/ an\%20business\%20deliver\%20Gray.pdf).

[4]. Edenkamp, Insights into how consumers are thinking, how they are acting and why, Brand week, 43 (36), $2002,16-20$.

[5]. Levitt, The dangers of social responsibility. In T. Meloan, S. Smith, \& J. Wheatly (Eds.), Managerial marketing policies and decisions. (Houghton Mifflin, Boston, 1970).

[6]. Friedman, The Social Responsibility of Business is to Increase its Profit, The New York Times Magazine, Sept 13, $1970,122-126$.

[7]. Donaldson and Dunfee, Ties that Bind: A Social Contract Approach to Business Ethics, (Harvard Business School Press, Boston, 1999).

[8]. ones, Instrumental Stakeholder Theory: A Synthesis of Ethics and Economics, Academy of Management Review, 20(2), 1995, 404-437.

[9]. oon, Corporate Social Responsibility: An Overview in International Directory of Corporate Philanthropy, (Europa Publications, London, 2002).

[10]. Mohan, Corporate Citizenship: Perspectives from India, Journal of Corporate Citizenship, Spring, 2001 107-117.

[11]. Chambers, E., Chapple, W., Moon, J. \& Sullivan, M. (n.d). CSR in Asia: A seven-country study of CSR website reporting. (Www.nottingham.ac.uk/business/ICCSR/09-2003.PDF).

[12]. Palazzo and Scherer, Corporate Legitimacy as Deliberation. A Communicative Framework, Journal of Business Ethics, 66 (1), (2006), 71-88.

[13]. OECD,CorporateResponsibility:PrivateInitiativesandPublicGoals,OECD,2001OECD, Environment and the OECD Guidelines for Multinational Enterprises: Corporate Tools and Approaches, OECD, 2005 (www.oecd.org).

[14]. Jayaraman,N.(2002).CocaColaparchesagriculturallandinIndia. (http://www.globalpolicy.org/globaliz/special/2002/0528india.htm)

[15]. Srivastava,A.(2004).Cokewithyetanothernewtwist:Toxiccola. http://www.indiaresource.org/campaigns/coke/2004/coketwist.html).

[16]. Iype, G. (2003). Sludge at coke factory is deadly. (http://www.rediff.com/money/2003/aug/05spec 2 .htm). 